\title{
The effects of hepatitis $C$ virus core protein on the expression of miR-122 in vitro
}

\author{
Sujuan $\mathrm{Li}^{1}$, Xiaokang Xing ${ }^{1}$, Qiao Yang ${ }^{1}$, Hangdi Xu' ${ }^{1}$, Jiliang $\mathrm{He}^{2}$, Zhi Chen ${ }^{1}$ and Haihong Zhu ${ }^{1 *}$
}

\begin{abstract}
Background: Hepatitis C virus (HCV) is one of the major pathogens of liver diseases. Some studies have previously reported that miR-122 can stimulate replication or translation of HCV. However, the effects of HCV infection on miR122 expression are not clear. The aim of this study was to investigate the effects of HCV core protein on the expression of miR-122 in a cell culture model.

Results: The miR-122 levels in Huh7.5.1 cells infected with HCV for different days or different HCV abundance were measured by real-time PCR. Significant decrease of miR-122 expression was found at late stage of infection and in the high-abundance group. Huh7.5.1 cells transfected with plasmid pEGFP-core or pEGFP were used to detect the effects of HCV core protein on miR-122 expression, the results showed that core protein could down-regulate the miR-122 expression level in a time- and dose- dependent manner, and reduced the susceptibility of Huh7.5.1 cell to $\mathrm{HCV}$.
\end{abstract}

Conclusions: Down-regulating miR-122 expression by HCV core protein may give a new insight into the interaction between HCV and miR-122 and chronic HCV infection.

\section{Background}

Hepatitis $\mathrm{C}$ virus (HCV) is one of the major causes of viral hepatitis and hepatocellular carcinoma, which infects an estimated 170 million people throughout the world [1,2]. Currently, pegylated interferon- $\alpha$ (IFN- $\alpha)$ combined with ribavirin is the standard of care for chronic HCV infection. The therapy has a sustained virological response rate of $40 \% \sim 50 \%$ in patients with genotype $1 \mathrm{HCV}$ infection [3-5], which accounts for the majority of the hepatitis $\mathrm{C}$ patient population in the developed countries. A range of non-structural protease inhibitors are developed to act as antiviral agents against $\mathrm{HCV}$, such as boceprevir $[6,7]$ and telaprevir $[8,9]$. However, genetic heterogeneity between $\mathrm{HCV}$ genotypes influences the structure of protease and limits the effectiveness of the antivirals [10]. Most people infected with HCV develop chronic liver disease [11]. The success of $\mathrm{HCV}$ in persisting is linked to its overall ability to evade antiviral defences. Several HCV structural and nonstructural proteins, including Core [12,13], E2 [14],

\footnotetext{
*Correspondence: zhuhh72@zju.edu.cn

'State Key Laboratory for Diagnosis and Treatment of Infectious Diseases, Institute of Infectious Diseases, the First Affiliated Hospital, School of Medicine, Zhejiang University, Hangzhou 310003, China

Full list of author information is available at the end of the article
}

NS3/4A [15,16] and NS5A [17] proteins, have been shown to inhibit the innate immune response.

miRNAs are post-transcriptional regulators that bind to complementary sequences on target messenger RNA transcripts (mRNAs), usually resulting in translational repression or target degradation and gene silencing. miR122, a liver-specific miRNA expressed at high levels in hepatocytes, constitutes $70 \%$ of the total miRNA in the liver [18]. miR-122 enhanced the replication of HCV through a direct interaction with the 5'noncoding region (NCR) of the HCV genome [19]. Henke et al. showed that miR-122 stimulated translation of $\mathrm{HCV}$ by enhancing the association of ribosomes with the viral RNA [20]. Furthermore, it was proved that up-regulation of HMOX1, which was the target gene of miR-122, decreased HCV RNA [21]. However, the effects of $\mathrm{HCV}$ on the expression of miR122 haven't been fully explored yet.

In the current study, a cell culture model based on Jc1 clone and Huh7.5.1 cell was used to investigate the effects of HCV on the expression of miR-122. Data showed that HCV decreased the expression of miR-122 in a time- and dose- dependent manner. Further results revealed that the $\mathrm{HCV}$ core protein performed this 
function. These results give a novel insight into the interaction between HCV and miR-122.

\section{Results}

HCV decreased the expression of miR-122 in a time- and dose- dependent manner

Huh7.5.1 cells infected with HCV Jc1 virus were used in the following studies to determine whether HCV replication would regulate the expression of miR-122. Cells were harvested at different time points, and the relative expressions of HCV RNA and miR-122 were determined by real-time PCR. Intracellular HCV RNA increased rapidly and reached the highest level at 26 days postinfection (Figure 1A), which was further confirmed by immunofluorescence staining (Figure 1B). These results suggested that $\mathrm{HCV}$ replicated effectively in infected Huh7.5.1 cells. miR-122 expression increased to the maximum level of $157 \%$ (vs day 3 ) at day 19 post-infection (Figure 1A), then decreased quickly and reached the minimum level of $50 \%$ (vs day 3) at day 32 post-infection (Figure 1A). At day 26, day 29 and day 32 post-infection, corresponding to the high levels of HCV RNA, intracellular levels of miR-122, however, decreased to $86 \%, 62 \%$ and $50 \%$, respectively (vs day 3 ) (Figure $1 \mathrm{~A}$ ). The experiment
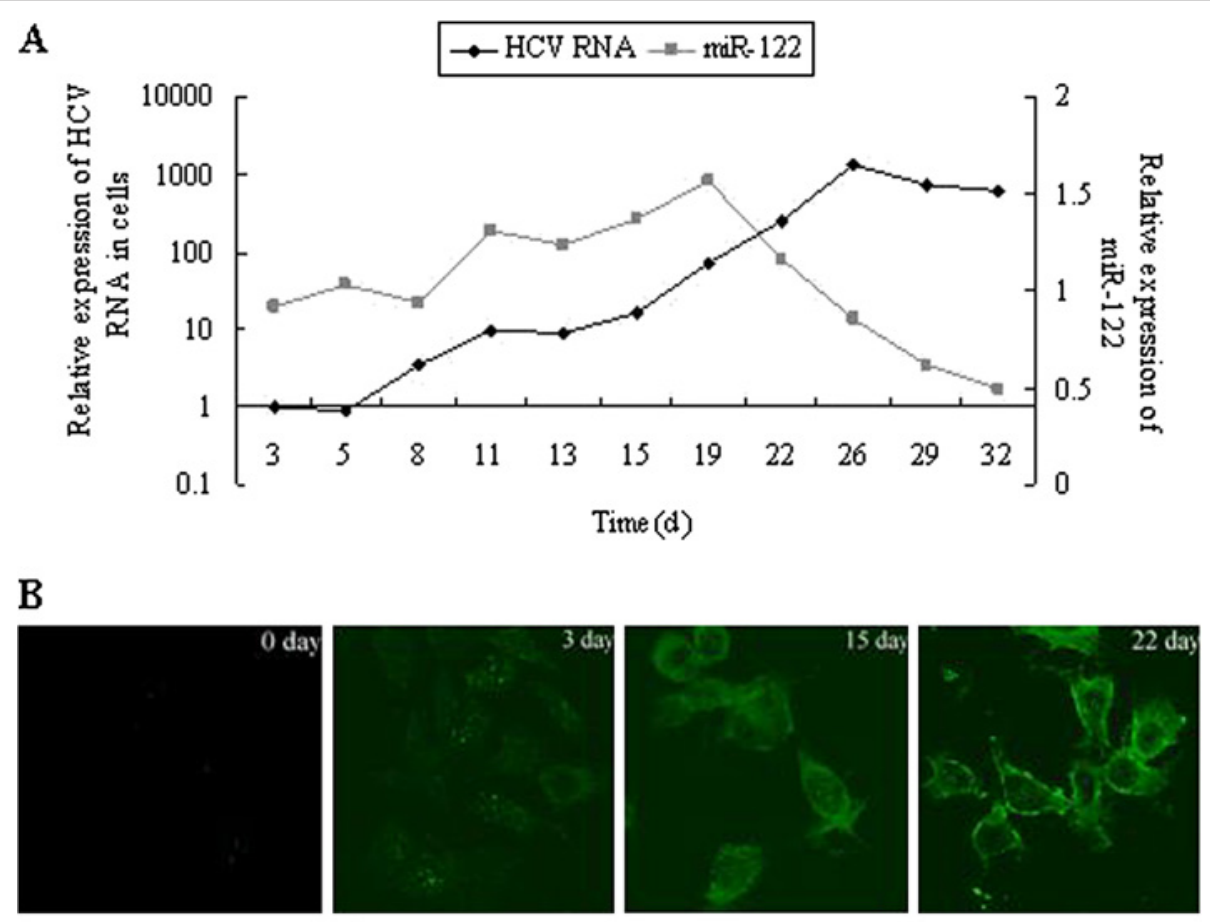

$\mathrm{C}$
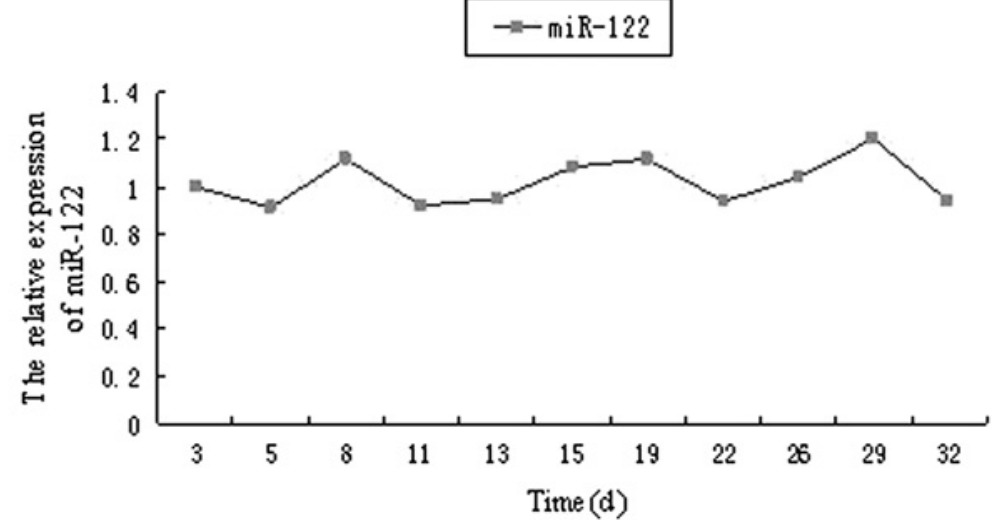

Figure 1 Replication of HCV and expression of miR-122 in Huh7.5.1 cells after infection with HCV. (A) Huh7.5.1 cells infected with $2 \times$ $10^{6} \mathrm{IU} / \mathrm{ml} \mathrm{HCV}$ particles were harvested at the indicated time points post-infection. Intracellular HCV RNA and miR-122 were analyzed by real-time PCR, using 3 days post-infection as control group. (B) Intracellular expression of HCV core protein was assessed by indirect immunofluorescent staining. (C) Uninfected huh7.5.1 cells were cultured for 32 days as parallel control group. Intracellular miR-122 was analyzed by real-time PCR, using 3 days as control group. 
was repeated three times, during which our observation and data were quite consistent with the Figure 1A. In contrast, there were no significant changes in expressions of miR-122 in uninfected group throughout the experiment (Figure 1C).

To determine whether miR-122 expression was related with the amount of $\mathrm{HCV}$, we infected Huh7.5.1 cells with different amounts of HCV for 10 days. The expression of HCV RNA in each group $\left(10^{5} \mathrm{IU} / \mathrm{ml}\right.$ group, $10^{6} \mathrm{IU} / \mathrm{ml}$ group and $10^{7} \mathrm{IU} / \mathrm{ml}$ group) increased to different levels $(P<0.05$ or $P<0.01)$ (Figure $2 \mathrm{~A})$. We then measured the expression of miR-122 in each group. There was a $\sim 47 \%$ decrease of miR-122 expression with statistical significance in the $10^{7} \mathrm{IU} / \mathrm{ml}$ group $\left(10^{7} \mathrm{IU} / \mathrm{ml}\right.$ $0.53 \pm 0.12$ vs control $0.97 \pm 0.09 P<0.05$ ) (Figure $2 \mathrm{~B}$ ). In contrast, no significant differences were observed in the $10^{5} \mathrm{IU} / \mathrm{ml}$ group and $10^{6} \mathrm{IU} / \mathrm{ml}$ group (Figure $2 \mathrm{~B}$ ).

HCV core protein down-regulated miR-122 expression

To evaluate whether HCV core protein affected the expression of miR-122, we transfected Huh7.5.1 cells with plasmid pEGFP-core expressing GFP-tagged HCV core protein or plasmid pEGFP (Figure 3A). miR-122 expression was detected in the Huh7.5.1 cells at $24 \mathrm{~h}, 48 \mathrm{~h}$ and
$72 \mathrm{~h}$ post-transfection. HCV core protein suppressed miR-122 expression in a time-dependent manner $(24 \mathrm{~h}$ $0.71 \pm 0.114,48$ h $0.60 \pm 008,72$ h $0.45 \pm 0.121$, vs control $1.06 \pm 0.406, P<0.05$ or $P<0.01$ ) (Figure $3 \mathrm{~B}$ ). The suppression effect of $\mathrm{HCV}$ core protein was also dosedependent since the level of miR-122 was proportionally reduced when increasing amounts of $\mathrm{HCV}$ core protein were transfected into cells $(0.5 \mu \mathrm{g} 0.80 \pm 0.112,1 \mu \mathrm{g}$ $0.74 \pm 0.086,2 \mu \mathrm{g} 0.64 \pm 0.082$, vs control $1.01 \pm 0.179$, $P<0.05$ or $P<0.01$ ) (Figure $3 C$ ). In contrast, GFP protein had no significant effect on miR-122 expression (Figure 3B) (Figure 3C).

\section{HCV core protein down-regulated susceptibility of Huh7.5.1 cells to HCV}

Subsequently, Huh7.5.1 cells transfected with different doses of plasmid pEGFP-core or pEGFP were infected with $\mathrm{HCV}$ to investigate whether core protein influenced the susceptibility of Huh7.5.1 cells to HCV. Actually, HCV RNA levels in groups transfected with plasmid pEGFP-core decreased when compared to pEGFP group $(0.5 \mu \mathrm{g} 0.58 \pm 0.088,1 \mu \mathrm{g} 0.49 \pm 0.058,2 \mu \mathrm{g} 0.36 \pm 0.098$ vs control $0.94 \pm 0.08, P<0.05$ or $P<0.01$ ) (Figure 4 ). In contrast, there wasn't an obvious change of HCV RNA
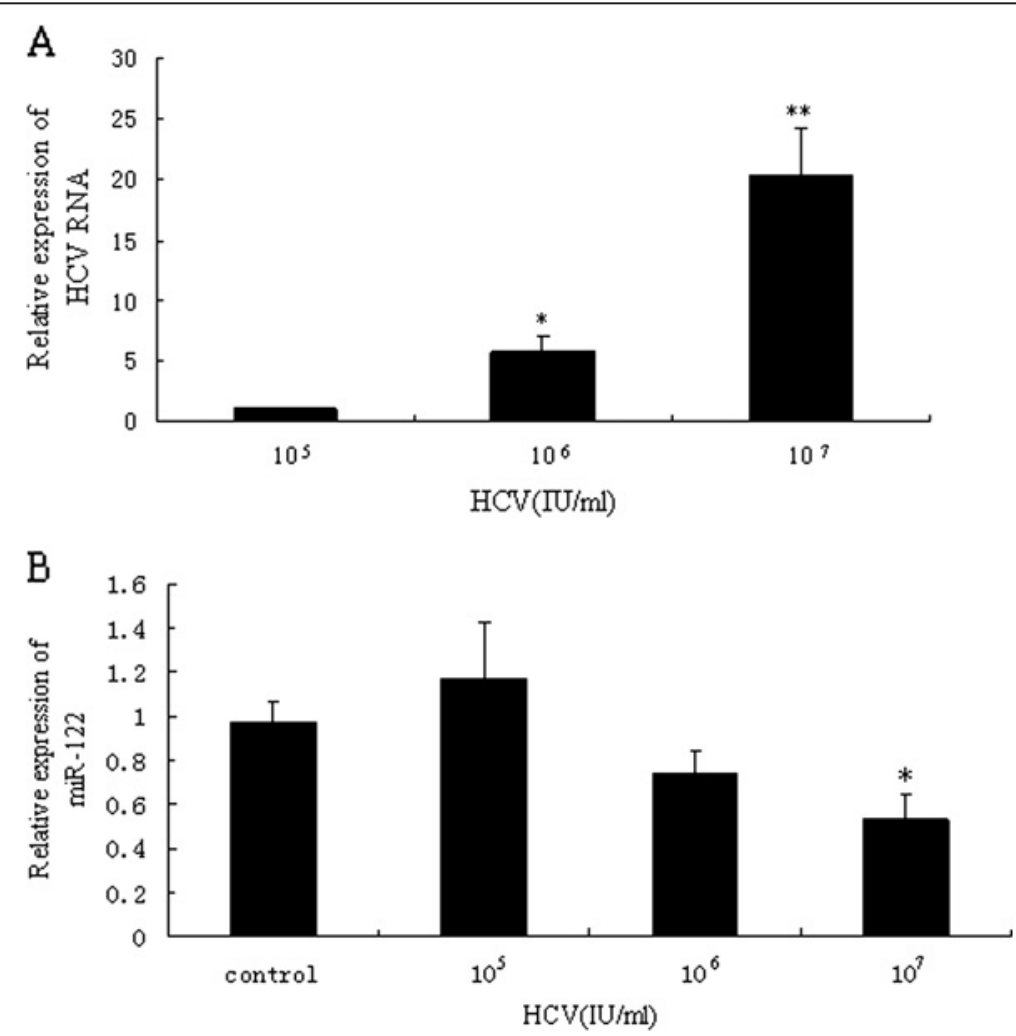

Figure 2 Expressions of HCV RNA and miR-122 in Huh7.5.1 cells after infection with different levels of HCV. (A) Intracellular expressions of HCV RNA in Huh7.5.1 cells infected with different levels of HCV were assayed, using $10^{5} \mathrm{IU} / \mathrm{ml}$ group as control group. (B) Intracellular expressions of miR-122 in Huh7.5.1 cells infected with different levels of HCV were assayed, using mock group as control group. The data were presented as means \pm SD of three independent experiments. ${ }^{*} P<0.05,{ }^{* *} P<0.01 \mathrm{vs}$. control group. 


\section{A}
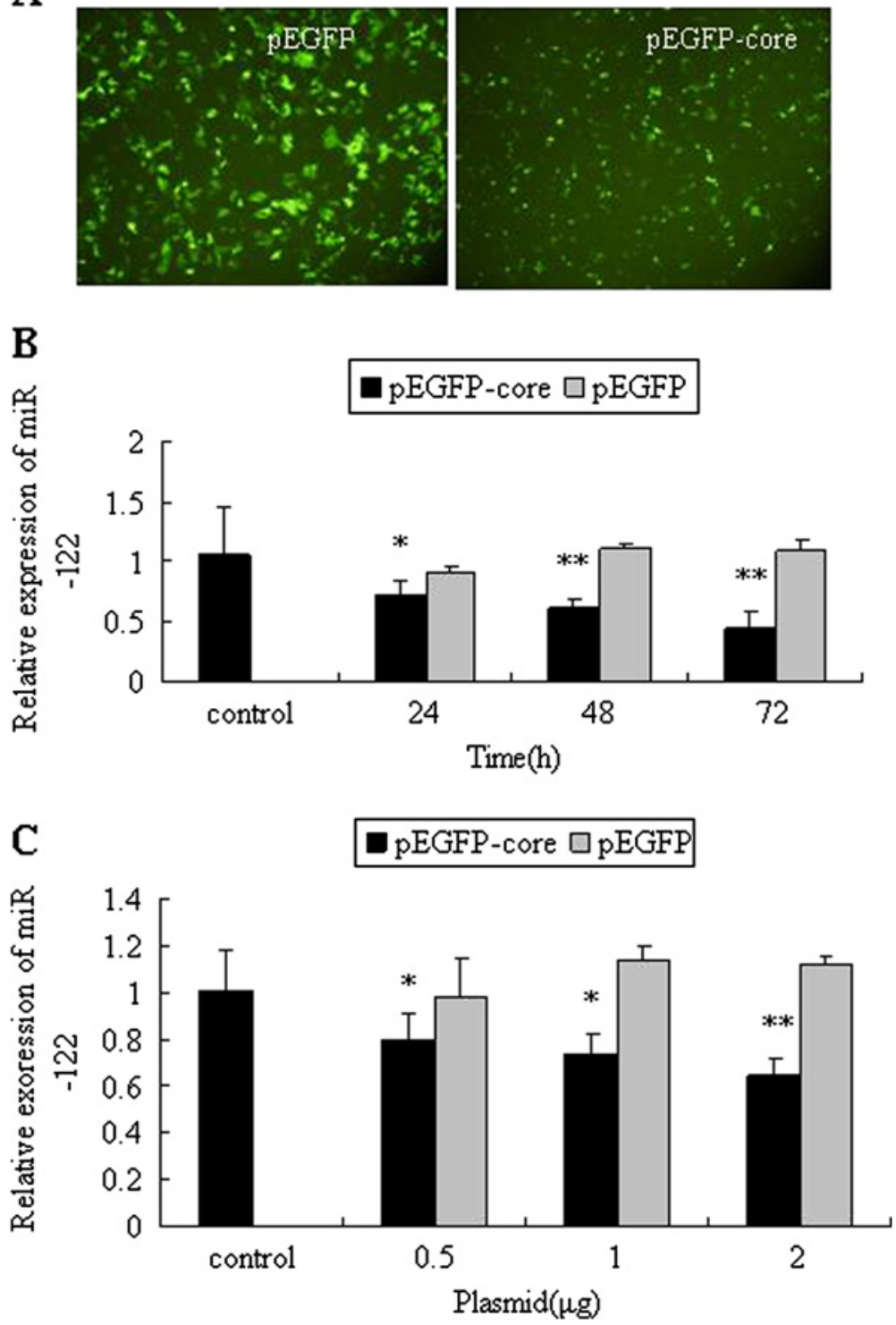

Figure 3 HCV core protein suppressed the expression of miR-122. (A) The intensity of EGFP in Huh7.5.1 cells transfected with plasmid pEGFP-core or pEGFP was observed by fluorescence microscopy. (B) Huh7.5.1 cells transfected with $1.5 \mu \mathrm{g}$ of plasmid pEGFP-core or pEGFP were harvested at $24 \mathrm{~h}, 48 \mathrm{~h}$ and $72 \mathrm{~h}$ posttransfection. The relative expression of miR-122 was detected, using mock group as control group. (C) miR122 expressions in Huh7.5.1 cells transfected with $0.5 \mu \mathrm{g}, 1 \mu \mathrm{g}$ and $2 \mu \mathrm{g}$ of the plasmid pEGFP-core or pEGFP were detected at $48 \mathrm{~h}$ posttransfection, using mock group as control group. The data were presented as means \pm SD of three independent experiments. ${ }^{*} P<0.05,{ }^{* *} P<$ 0.01 vs. control group.

expression in pEGFP group when compared to control group (Figure 4).

\section{Discussion}

It is generally believed that miR-122, specifically expressed and highly abundant in the liver, facilitates replication of $\mathrm{HCV}$. That is the reason why HCV RNA can only replicate in Huh7 cells, but not in HepG2 cells, which do not express endogenous miR-122 [19].
In recent years, many studies have focused on the relationship between HCV and miR-122. There is, however, only limited information about the role of HCV in miR122 expression. In our study, the intracellular levels of HCV RNA and miR-122 were measured at different time points after infecting with $\mathrm{HCV}$. The results indicated that the level of HCV RNA increased rapidly during the infection, and there was a positive correlation between miR-122 level and HCV RNA level at the early stage of infection to some extent. However, in previous reports, 


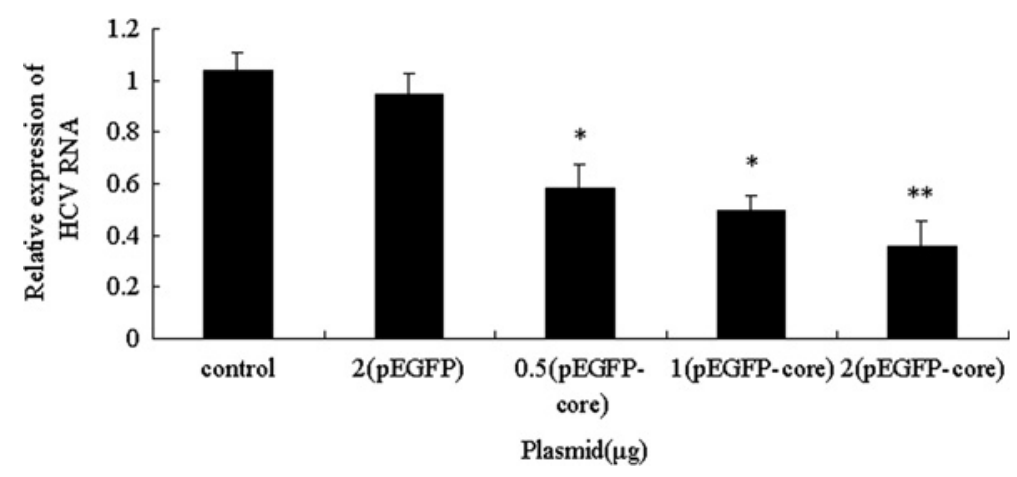

Figure 4 The susceptibility of Huh7.5.1 cells to HCV after transfection with plasmid pEGFP-core or pEGFP. Huh7.5.1 cells were transfected with $0.5 \mu \mathrm{g}, 1 \mu \mathrm{g}$ and $2 \mu \mathrm{g}$ of the plasmid pEGFP-core or pEGFP for $48 \mathrm{~h}$, and then infected with $1 \times 10^{7} \mathrm{IU} / \mathrm{ml} \mathrm{HCV}$ particles for $72 \mathrm{~h}$. Relative level of HCV RNA was quantified by real-time PCR, using $72 \mathrm{~h}$ post-infection as control group. The data were presented as means \pm SD of three independent experiments. ${ }^{*} P<0.05,{ }^{* *} P<0.01$ vs. pEGFP group. $P>0.05$ pEGFP group vs. control group.

no positive correlation was observed between miR-122 level and HCV [22,23]. It may be due to not strong correlation between miR-122 level and HCV RNA level or the different cell line. It was interesting that at day 19 after infection with $\mathrm{HCV}$, there was an inverse correlation between miR-122 expression and HCV RNA expression, and miR-122 expression level was obviously reduced at the late stage of $\mathrm{HCV}$ infection. This inverse correlation between $\mathrm{HCV}$ and miR-122 was consistent with a previous in vitro study, which reported that miR122 levels were significantly reduced on HCVcc infection [24]. It was also found in our study that miR-122 expression level decreased in high-abundance HCV group. In a vivo experiment, a similar result was observed that the HCV subjects with higher viral load had lower miR-122 levels in liver than HCV subjects with lower viral load [25]. Another similar result was published that hepatic miR-122 expression in serum HCV RNA-positive patients was significantly lower than that in serum HCV RNA-negative patients [26]. Thus, it seemed that, with the accumulation of $\mathrm{HCV}$, the inhibitory effect of $\mathrm{HCV}$ on miR-122 might be observed. Taken together, these results might support the notion that HCV monitors its replication by down-regulating the miR-122 level. Actually, a recently proposed hypothesis may provide a similar mechanistic explanation that, in order to survive, $\mathrm{HCV}$ need a steady viral replication rate [27-30]. By keeping abundance relatively low, the virus evades the immune response of the host and establishes persistent chronic infection.

The subsequent results demonstrated that it was $\mathrm{HCV}$ core protein that suppressed miR-122 expression both in a time- and dose- dependent manner. And overexpression of $\mathrm{HCV}$ core protein did reduce the susceptibility of Huh7.5.1 cells to $\mathrm{HCV}$, suggesting it might participate in the mechanism for self-regulation of $\mathrm{HCV}$, which might be important for viral persistence. However, further studies are needed to address the precise mechanism by which core protein functions.

\section{Conclusions}

That HCV core protein suppresses miR-122 expression may be involved in the mechanism of evading the immune response of the host.

\section{Methods}

\section{Plasmids}

HCV plasmid pFL-Jc1 was provided by Apath (Saint Louis, Missouri, USA). The plasmid pEGFP-core expressing GFPtagged HCV core protein and pEGFP were constructed in our laboratory.

\section{Cell culture}

The human hepatoma cell line Huh7.5.1 was kindly provided by Scott Forrest (Scripps Research Institute, La Jolla, CA, USA) and Jin Zhong (Institute Pasteur of Shanghai, China). Huh7.5.1 cells were maintained in Dulbecco's Modified Eagle Medium (Gibco) supplemented with $10 \%$ fetal bovine serum (Gibco), $100 \mathrm{U} / \mathrm{ml}$ of penicillin, $100 \mu \mathrm{g} / \mathrm{ml}$ of streptomycin and $2 \mathrm{mM} \mathrm{L}$-glutamine, at $37^{\circ} \mathrm{C}$ with $5.0 \% \mathrm{CO}^{2}$.

\section{HCV Jc1 virus preparation and infection}

In brief, the plasmid pFL-Jc1 was linearized by XbaI (New England Biolabs). Then HCV RNA was synthesized from the linearized DNA template with T7 RiboMAX ${ }^{\mathrm{TM}}$ Express Large Scale RNA Production System (Promega). Huh7.5.1 cells were regularly passaged and plated in 12well culture plates for $20 \mathrm{~h}$ before transfection at $60 \%$ confluency. In vitro transcribed HCV RNA was delivered into Huh7.5.1 cells by Lipofectamine 2000 (Invitrogen), according to the manufacturer's instructions. Transfected cells were passaged every $2-3$ days before the cells became confluent. The supernatant was collected at day 3 
or day 9 posttransfection and used as infectious $\mathrm{HCV}$ particles.

Naïve Huh7.5.1 cells plated in 12-well plate at a density of $4 \times 10^{4}$ cells per well were incubated with culture medium containing virus (50 IU/cell) for $4 \mathrm{~h}$ at $37^{\circ} \mathrm{C}$. Then the inoculum was discarded and fresh medium was added. Cells were passaged every $2-3$ days before the cells became confluent. For each passage, half of the cell culture supernatant was discarded and fresh medium was added.

\section{Transfection}

Huh7.5.1 cells were regularly passaged and plated in 12well culture plates for $20 \mathrm{~h}$ before transfection at 60\% confluency. Plasmids pEGFP-core or pEGFP were delivered into Huh7.5.1 cells by Lipofectamine 2000 (Invitrogen), according to the manufacturer's instructions.

\section{Real-time PCR detection}

HCV RNA in culture supernatant was quantified using diagnostic kit for quantification of hepatitis $\mathrm{C}$ virus RNA (Shanghai KeHua Bio-Engineering Co., Ltd.), according to the protocol. Tenfold serial dilutions of in vitro-transcribed HCV RNAs (from $10^{4}-10^{7} \mathrm{IU} / \mathrm{ml}$ ) served as standards, which were included in the Kit. In brief, HCV RNA in $100 \mu \mathrm{l}$ culture supernatant was extracted using nucleic acid extraction columns included in the kit. The $12.5 \mu \mathrm{l}$ of extracted RNA was amplified in each reaction well containing $7 \mu \mathrm{l}$ of PCR major reaction solution, $5 \mu \mathrm{l}$ of enzyme mixture and $0.5 \mu \mathrm{l}$ of probe. The temperature profile comprised the RT round conducted at $50^{\circ} \mathrm{C}$ for $25 \mathrm{~min}$ and the PCR rounds denaturing at $94^{\circ} \mathrm{C}$ for $2 \mathrm{~min}$ and then at $94^{\circ} \mathrm{C}$ for $10 \mathrm{~s}, 55^{\circ} \mathrm{C}$ for $15 \mathrm{~s}$ and $72^{\circ} \mathrm{C}$ for $15 \mathrm{~s}$, and completed by a 42 -cycle program at $94^{\circ} \mathrm{C}$ for $10 \mathrm{~s}$ and $60^{\circ} \mathrm{C}$ for $45 \mathrm{~s}$. Real-time PCR amplification was performed using the ABI 7500 system (Applied Biosystems).

Cellular RNA was extracted using Trizol (Invitrogen). For HCV RNA and GAPDH detection, RNA was reverse transcribed using the PrimeScript RT reagent Kit (Takara) and the cDNA production was quantified by Real-time PCR with SYBR Premix Ex Taq (Takara) according to the manufacturer's protocol. The primers sequence for $\mathrm{HCV}$ were: forward primer: GCGTTAGTATGAGTGTCGTG and reverse primer: TCGCAAGCACCCTATCAG and primers sequence for GAPDH were: forward primer: GAAGGTGAAGGTCGAGTC and reverse primer: GAA GATGGTGATGGGATTTC. For miRNA detection, RT and real-time PCR were performed using miRNA analysis kits (Applied Biosystems). The stem-loop RT primers and real-time primers for miR-122 and U6 were synthesized by Ribobio (Guangzhou, China).

\section{Indirect immunofluorescence}

Huh7.5.1 cells infected with HCV were seeded on coverslips in 12-well, then fixed in $4 \%$ paraformaldehyde for $10 \mathrm{~min}$ at $-20^{\circ} \mathrm{C}$. Fixed cells were permeabilized in $0.2 \%$ Triton-X100/PBS for $10 \mathrm{~min}$ at room temperature and blocked in a solution of $2 \% \mathrm{BSA} / \mathrm{PBS}$ for $30 \mathrm{~min}$ at room temperature. Then cells were incubated with anti-HCV Core antibody (Abcam) diluted $1: 500$, at $37^{\circ} \mathrm{C}$ for $2 \mathrm{~h}$, followed by anti-mouse IgG conjugated to Alexa 488 (Sigma) diluted 1:500, at $37^{\circ} \mathrm{C}$ for $1 \mathrm{~h}$. Coverslips were mounted on slides with $50 \%$ glycerol/PBS. Then, cells were examined by a Zeiss LSM 510 laser scanning confocal microscope.

\section{Statistical analysis}

Data were given as mean \pm SD obtained from three separate experiments. Statistical analysis was performed by using one-way ANOVA or by independent-sample Student's $t$-test, using SPSS ver. 11.5 software. P-values $<0.05$ were considered statistically significant.

\section{Competing interests}

The authors declare that they have no competing interests.

\section{Authors' contributions}

LSJ designed and executed the experiments, analyzed the data and wrote the manuscript. XXK, YQ and XHD assisted in performing the experiments. $\mathrm{ZHH}$ and $\mathrm{HJL}$ participated in manuscript preparation and revisions. $\mathrm{CZ}$ and $\mathrm{ZHH}$ designed the experiments and provided the financial support. All authors have read and approved the final version of the manuscript.

\section{Acknowledgements}

We would like to thank Scott Forrest and Jin Zhong for providing us with Huh7.5.1 cells and Apath for providing us with the pFL-Jc1 plasmid. This work was supported by Science and Technology Major Projects of Zhejiang Province (2009C03011-2) and National Science and Technology Major project (2012ZX10002-003).

\section{Author details}

${ }^{1}$ State Key Laboratory for Diagnosis and Treatment of Infectious Diseases, Institute of Infectious Diseases, the First Affiliated Hospital, School of Medicine, Zhejiang University, Hangzhou 310003, China. ${ }^{2}$ Institute of Environmental Medicine, Medical College, Zhejiang University, Hangzhou 310058, China.

Received: 5 March 2012 Accepted: 13 March 2013

Published: 27 March 2013

\section{References}

1. Lauer GM, Walker BD: Hepatitis C virus infection. N Engl J Med 2001, 345(1):41-52.

2. Rehermann B, Nascimbeni M: Immunology of hepatitis B virus and hepatitis C virus infection. Nat Rev Immunol 2005, 5(3):215-229.

3. Fried MW, Shiffman ML, Reddy KR, Smith C, Marinos G, Goncales FL Jr, Häussinger D, Diago M, Carosi G, Dhumeaux D, Craxi A, Lin A, Hoffman J, Yu $\mathrm{J}$ : Peginterferon alfa-2a plus ribavirin for chronic hepatitis $\mathrm{c}$ virus infection. N Engl J Med 2002, 347(13):975-982.

4. Hadziyannis SJ, Sette H Jr, Morgan TR, Balan V, Diago M, Marcellin P, Ramadori G, Bodenheimer H Jr, Bernstein D, Rizzetto M, Zeuzem S, Pockros PJ, Lin A, Ackrill AM, PEGASYS International Study Group: Peginterferonalpha2a and ribavirin combination therapy in chronic hepatitis C: a randomized study of treatment duration and ribavirin dose. Ann Intern Med 2004, 140(5):346-355.

5. Manns MP, MCHutchison JG, Gordon SC, Rustgi VK, Shiffman M, Reindollar R, Goodman ZD, Koury K, Ling M, Albrecht JK: Peginterferon alfa-2b plus 
ribavirin compared with interferon alfa- $2 b$ plus ribavirin for initial treatment of chronic hepatitis C: a randomised trial. Lancet 2001, 358(9286):958-965

6. Poordad F, McCone J Jr, Bacon BR, Bruno S, Manns MP, Sulkowski MS, Jacobson IM, Reddy KR, Goodman ZD, Boparai N, DiNubile MJ, Sniukiene V, Brass CA, Albrecht JK, Bronowicki JP, SPRINT-2 Investigators: Boceprevir for untreated chronic HCV genotype 1 infection. N Engl J Med 2011 364(13):1195-1206.

7. Bacon BR, Gordon SC, Lawitz E, Marcellin P, Vierling JM, Zeuzem S, Poordad F, Goodman ZD, Sings HL, Boparai N, Burroughs M, Brass CA, Albrecht JK, Esteban R, HCV RESPOND-2 Investigators: Boceprevir for previously treated chronic HCV genotype 1 infection. N Engl J Med 2011, 364(13):1207-1217.

8. Jacobson IM, McHutchison JG, Dscheiko G, Di Bisceglie AM, Reddy KR, Bzowej NH, Marcellin P, Muir AJ, Ferenci P, Flisiak R, George J, Rizzeto M Shouval D, Sola R, Terg RA, Yoshida EM, Adda N, Bengtsson L, Sankoh AJ, Kieffer TL, George S, Kauffman RS, Zeuzem S, ADVANCE Study Team: Telaprevir for previously untreated chronic hepatitis $C$ virus infetion. $N$ Engl J Med 2011, 364(25):2405-2416.

9. Zeuzem S, Andreone P, Pol S, Lawitz E, Diago M, Roberts S, Focaccia R Younossi Z, Foster GR, Hrban A, Ferenci P, Nevens F, Müllhaupt B, Pockros P, Terg R, Shouval D, Van Hoek B, Weiland O, Van Heeswijk R, De Meyer S, Luo D, Boogaerts G, Polo R, Picchio G, Beumont M, REALIZE Study Team: Telaprevir for retreatment of HCV infetion. N Engl J Med 2011, 364(25):2417-2428.

10. Inhof I, Simmonds P: Genotype differences in susceptibility and resistance development of hepatitis C virus to protease inhibitors telaprevir (VX950) and danoprevir (ITMN-191). Hepatology 2011, 53(4):1090-1099.

11. Flamm SL: Chronic hepatitis C virus infection. JAMA 2003, 289(18):2413-2417

12. Melen $K$, Fagerlund $R$, Nyqvist M, Keskinen $P$, Julkunen I: Expression of hepatitis $C$ virus core protein inhibits interferon-induced nuclear import of STATs. J Med Virol 2004, 73(4):536-547.

13. Miller K, McArdle S, Gale MJ Jr, Geller DA, Tenoever B, Hiscott J, Gretch DR, Polyak SJ: Effects of the hepatitis $C$ virus core protein on innate cellular defense pathways. J Interferon Cytokine Res 2004, 24(7):391-402.

14. Taylor DR, Shi ST, Romano PR, Barber GN, Lai MM: Inhibition of the interferon-inducible protein kinase PKR by HCV E2 protein. Science 1999, 285(5424):107-110.

15. Li K, Foy E, Ferreon JC, Nakamura M, Ferreon AC, Ikeda M, Ray SC, Gale M Jr, Lemon SM: Immune evasion by hepatitis $C$ virus NS3/4A proteasemediated cleavage of the Toll-like receptor 3 adaptor protein TRIF. Proc Natl Acad Sci USA 2005, 102(8):2992-2997.

16. Li XD, Sun L, Seth RB, Pineda G, Chen ZJ: Hepatitis C virus protease NS3/ $4 \mathrm{~A}$ mitochondrial antiviral signaling protein off the mitochondria to evade innate immunity. Proc Natl Acad Sci USA 2005, 102(49):17717-17722.

17. Song J, Fujii M, Wang F, Itoh M, Hotta H: The NS5A protein of hepatitis C virus partially inhibits the antiviral activity of interferon. J Gen Virol 1999, 80(Pt 4):879-886.

18. Chang J, Nicolas E, Marks D, Sander C, Lerro A, Buendia MA, Xu C, Mason WS, Moloshok T, Bort R, Zaret KS, Taylor JM: miR-122, a mammalian liverspecific microRNA, is processed from hcr mRNA and may downregulate the high affinity cationic amino acid transporter CAT-1. RNA Biol 2004, 1(2):106-113.

19. Jopling $C L$, Yi M, Lancaster AM, Lemon SM, Sarnow P: Modulation of hepatitis $C$ virus RNA abundance by a liver-specific MicroRNA. Science 2005, 309(5740):1577-1581.

20. Henke Jl, Goergen D, Zheng J, Song Y, Schüttler CG, Fehr C, Jünemann C, Niepmann M: microRNA-122 stimulates translation of hepatitis $C$ virus RNA. EMBO J 2008, 27(24):3300-3310.

21. Shan Y, Zheng J, Lambrecht RW, Bonkovsky HL: Reciprocal effects of micro-RNA-122 on expression of heme oxygenase- 1 and hepatitis $C$ virus genes in human hepatocytes. Gastroenterology 2007, 133(4):1166-1174.

22. Cermelli S, Ruggieri A, Marrero JA, loannou GN, Beretta L: Circulating microRNAs in patients with chronic hepatitis $C$ and non-alcoholic fatty liver disease. PLoS One 2011, 6(8):e23937.

23. Randall G, Panis M, Cooper JD, Tellinghuisen TL, Sukhodolets KE, Pfeffer S, Landthaler M, Landgraf P, Kan S, Lindenbach BD, Chien M, Weir DB, Russo J, Ju J, Brownstein MJ, Sheridan R, Sander C, Zavolan M, Tuschl T, Rice CM: Cellular cofactors affecting hepatitis $C$ virus infection and replication. Proc Natl Acad Sci USA 2007, 104(31):12884-12889.
24. Marquez RT, Bandyopadhyay S, Wendlandt EB, Keck K, Hoffer BA, Icardi MS, Christensen RN, Schmidt WN, McCaffrey AP: Correlation between microRNA expression levels and clinical parameters associated with chronic hepatitis C viral infection in humans. Lab Invest 2010, 90(12):1727-1736.

25. Sarasin-Filipowicz M, Krol J, Markiewicz I, Heim MH, Filipowicz W: Decreased levels of microRNA miR-122 in individuals with hepatitis $C$ responding poorly to interferon therapy. Nat Med 2009, 15(1):31-33.

26. Morita K, Taketomi A, Shirabe K, Umeda K, Kayashima H, Ninomiya M, Uchiyama H, Soejima Y, Maehara Y: Clinical significance and potential of hepatic microRNA-122 expression in hepatitis C. Liver Int 2011, 31(4):474-484

27. Sallie R: Replicative homeostasis: a mechanism of viral persistence. Med Hypotheses 2004, 63(3):515-523.

28. Sallie R: Replicative homeostasis: a fundamental mechanism mediating selective viral replication and escape mutation. Virol J 2005, 2:10.

29. Sallie R: Replicative homeostasis II: influence of polymerase fidelity on RNA virus quasispecies biology: implications for immune recognition, viral autoimmunity and other "virus receptor" diseases. Virol J 2005, 2:70

30. Sallie R: Replicative homeostasis III: implications for antiviral therapy and mechanisms of response and non-response. Virol J 2007, 4:29.

doi:10.1186/1743-422X-10-98

Cite this article as: Li et al:: The effects of hepatitis $C$ virus core protein on the expression of miR-122 in vitro. Virology Journal 2013 10:98.

\section{Submit your next manuscript to BioMed Central and take full advantage of:}

- Convenient online submission

- Thorough peer review

- No space constraints or color figure charges

- Immediate publication on acceptance

- Inclusion in PubMed, CAS, Scopus and Google Scholar

- Research which is freely available for redistribution

Submit your manuscript at www.biomedcentral.com/submit
C Biomed Central 